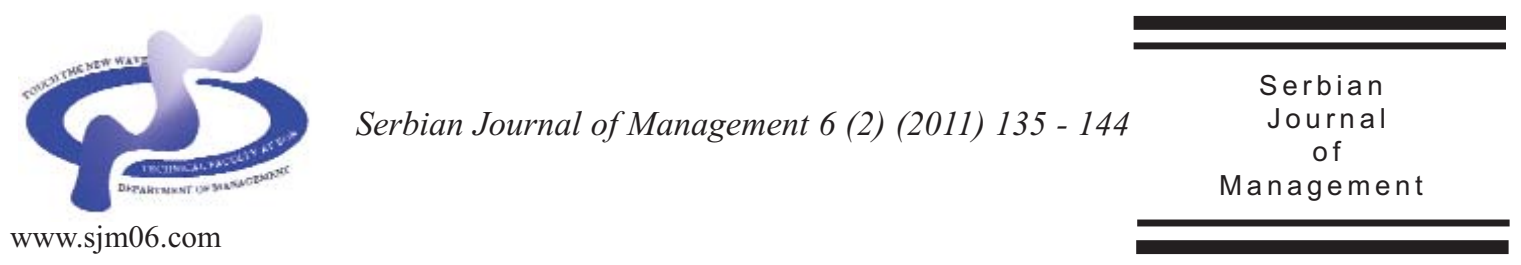

\title{
TECHNOLOGICAL PROCESS MODELING AIMING TO IMPROVE ITS OPERATIONS MANAGEMENT
}

\author{
Ivan Mihajlovića ${ }^{a *}$, Nada Štrbac ${ }^{a}$, Predrag Đorđevića \\ Aleksandra Ivanovié ${ }^{b}$ and Živan Živkovića

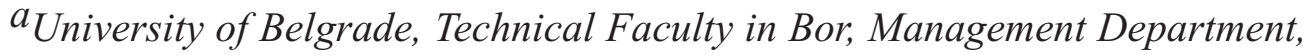 \\ Vojske Jugoslavije 12, 19210 Bor, Serbia

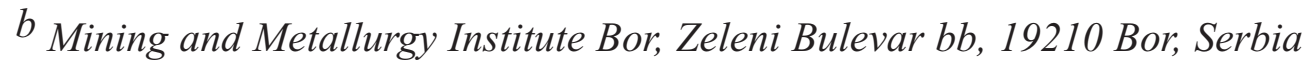

(Received 17 May 2011; accepted 28 September 2011)

\begin{abstract}
This paper presents the modeling procedure of one real technological system. In this study, the copper extraction from the copper flotation waste generated at the Bor Copper Mine (Serbia), were the object of modeling. Sufficient data base for statistical modeling was constructed using the orthogonal factorial design of the experiments. Mathematical model of investigated system was developed using the combination of linear and multiple linear statistical analysis approach. The purpose of such a model is obtaining optimal states of the system that enable efficient operations management. Besides technological and economical, ecological parameters of the process were considered as crucial input variables.
\end{abstract}

Keywords:Process modeling, statistical analysis, experimental design.

\section{INTRODUCTION}

The purpose of each investigation, which is the scientific cognition of the reality, is based on the aspiration to determine the facts characterizing referred object, the process or the aspect. It is obvious that the first stage in such efforts is data collection by observing or measurement, which is the starting point toward determination of the model, that has to assert the information about the object, included in the results of the observations. This can be explained by the fact that each separate result of observing the same system has, more or less, similar character (yet not identical). This way, projecting credible model of the real object can be facilitated after multiple and often consecutive observations.

Developing the accurate model of the

\footnotetext{
*Corresponding author: imihajlovic@tf.bor.ac.rs
}

DOI: $10.5937 /$ sjm 1102135M 
technological process is of essential importance considering that this is enabling much easier way of the process parameters acquisition, which is important for the operations management. Operations management complexity, of the contemporary technological processes, is even increasing during the $21^{\text {st }}$ century. The reason for this should be found in the fact that contemporary technological processes require optimization of not only the technical - technical and economical, but the ecological aspects as well.

Successful operations planning of any process of contemporary management, is supposing preparatory defining the process model, comprehending all technical, economical and ecological parameters (Mihajlovic et al., 2009). The aims of system (process) modeling are:

- Using the model instead of real system to achieve system parameters;

- Avoiding the risk of experiments on real system;

- Obtaining the results whose analysis should enable effective operational management of the real system;

- Less expenses resulting from model, instead of system, optimization.

\section{TYPES OF MODELS}

Besides intensive development of the modeling methods, in different fields of science and technology, it can be stated that unique classification of all types of models isn't developed yet. Having this in mind, general classification is placing all models in one of two groups: the class of symbolic and the class of real (physical, material) models.

Symbolic models are describing the object, process or appearance on some of languages (symbols) characteristically for the objects nature. To further explain the symbolic language, it should be started from the fact that each scientific field developed its own symbols during its historical evaluation. The first language used to describe each scientific discipline was, of course, verbal language. Next scientific language was the language of mathematics pronounced by its symbolic abbreviations, relations and logical dependences. Subsequently, each scientific and technical field developed its own language of the symbols. However, resulting from the intensive development of informational technology, the possibilities for modeling different appearances are strongly increasing. This again leads to the certain standardization of symbolic models and their broad application which leads to generality of computer simulation and modeling implementation. Accordingly, mathematical language once again becomes major modeling tool. Each scientific field is subsequently adjusting its symbolism to standard mathematical expressions (Mihajlovic, et al., 2009).

Real models (material of physical) are presenting the second class of models. The examples of these types of models are different laboratory installments constructed according to the theory of congeniality, the set up of the process or production facility, etc (Meijie et al., 2011). The development of any business or technological process could not be imagined without this type of modeling, in the past. In modern engineering practice utilization of such models is rear. Namely, utilization of real models is more and more suppressed by computer simulations techniques based on CAD computer systems. Hence, it is not mandatory that the simulation has to include 
the symbolic model of an object. It can be computer imitation of the classical physical model of the process.

\section{SYSTEM MODELING TECHNIQUES}

Aware of the fact that mathematical model has to mirror the real process as better as possible, as well as the cognition of the limits to which contemporary mathematical apparatus can reach; the question of level of real process idealization arises. Accordingly, primary characteristics of the process should not be neglected, on one hand, while mathematical model should not be to complex, on the other. Too complex mathematical model is lingering the subsequent mathematical analysis.

First modeling technique (M1) is based on the assumption that the mathematical mode of an object is presented in the form of differential equations assemble. With systems presented by differential equations assemble the structure of the model is emerging directly from the known theoretical background and scientific validity of the system. Accordingly, it is necessary to know the structure of the investigated system. The solutions of the differential equations assemble can be obtained using the computer simulation after introducing standard input signals. Then, real system (the object) is induced with the same input signals while the output (response) of the system is measured. Comparing the results of the differential equations solution with the outputs of the real system, the conclusions on validity of constructed model can be brought. However, since there is no linear system existing in the nature, success of this modeling procedure is based on differential equations linearization, in the surrounding of an equilibrium point. This is resulting in difficulties of complex systems modeling, which can have more than one stabile state and this way many equilibrium points (Wair, 1991; Brown, 2007; Đorđević et al., 2010).

The real systems dynamics is additionally aggravating this modeling approach.

The second modeling approach (M2) is based on experimentally obtained functional dependences of the real object under the non stationary regime. Using the measured output of the system, obtained after introducing predefined inputs, mathematical model of the object can be defined. In this case it is not necessary to know the structure of the system (relations among the elements, number of elements and their characteristics). Sufficient is to collect the outputs, after introducing predefined inputs to the system, and this way to form a data base which can be used for further modeling procedure. This is why, this type of modeling, is called a "black box modeling" (Taylor et al., 2003; Giraldo-Zuniga et al., 2006; Mihajlović et al., 2009). This type of real process modeling is attaining more and more application in the operations management, because of the practical reasons based on its applicability.

\section{MODELING OF TECHNOLOGICAL PROCESSES}

Having in mind the complexity of contemporary technological processes, modeling procedure M1 is too complicated in most of the cases. Contemporary practice of operational management of technological processes is most often based on M2 modeling methodology. In this modeling approach, both analytical and statistical modeling tools can be applied. In the case of 
analytical approach, existing model equations are tested on investigated system, while in the case of statistical approach, linear (MLRA) and nonlinear (ANN) statistical methods can be applied (Mihajlović et al., 2009; Mihajlović et al., 2010).

This way, contemporary operations management of complex technological processes is usualy based on process modeling, based on statistical methods.

\section{OBJECT OF MODELING}

Copper extraction from the flotation waste, disposed as the byproduct of the Bor Copper Mine (Serbia), was used as one example of the industrial process whose technological and ecological parameters were the subject of optimization. The reason for investigating this system is based on the fact that the copper flotation waste generally contains significant amounts of $\mathrm{Cu}$ together with trace elements of other toxic metals such as $\mathrm{Ni}, \mathrm{Zn}, \mathrm{Co}$ and $\mathrm{Pb}$. This way, the copper flotation waste generated from the copper industry is classified as "Hazardous waste" according to European Union directive concerning integrated pollution prevention (EU directive, 1996) as well as the Mining Waste directive (EU directive, 2006).

In the RTB-Bor Company, Serbia, the annual amount of flotation waste is about 20 Mt. Bearing in mind that waste was accumulated in earlier years without any processing, it is estimated that about $10^{9}$ tones of waste have been stored at this deposit (Djuric et al, 2010). Large area cowered with the tailing is a source of mineral dust. The dust from this location, in the form of $\mathrm{PM}_{2.5}$ and $\mathrm{PM}_{10}$, is dispersed towards the urban area and the areas of fertile land depending on the wind rose and the time of the year.

In the wider area surrounding flotation tailings ponds, there are around 200,000 inhabitants whose health is imperiled by the soil and water intoxication.

This way, the idea of this work is to investigate the possibility of copper utilization from the flotation waste collected from the copper industry in Bor during the years of extraction. Having in mind high copper price at the Worlds market, this will generate additional income which could be partially used for remediation and safe disposal of the waste material remaining after the copper extraction. To design the equipment for copper leaching from this raw material, the leaching process had to be firstly modeled on a laboratory scale.

\section{EXPERIMENTAL PROCESS DESIGN}

To obtain sufficiently large data base for construction of the adequate process model, using the M2 methodology, it is necessary to perform careful selection of the influencing process parameters (inputs of the process). Subsequently it is necessary to measure the outputs of the system, under controlled scope of selected input variables. As the tool for determining the optimal scope of input process parameters orthogonal (factor) design is widely applied.

As already indicated, copper extraction from the copper flotation waste was the subject of modeling procedure, described in this work. To obtain a reliable statistical model, prior knowledge of the procedure is generally required. This way, in this study, eight operating factors were identified as 
independent input variables. The technical procedure of the experiments is based on mixing the copper containing raw material with the sulphoric acid in different solid to liquid ratios (variable $\mathrm{X}_{1}$ ) (in the form of paste), heating the paste to temperatures up to $250^{\circ} \mathrm{C}$ (variable $\mathrm{X}_{2}$ ), during time periods up to 12 hours (variable $\mathrm{X}_{3}$ ). Following step is leaching the roasted material in the water with different solid to liquid ratio (variable $\mathrm{X}_{4}$ ), at different temperatures (variable $\mathrm{X}_{5}$ ) and during different time intervals (variable $\mathrm{X}_{6}$ ). Next important variables are the rate of agitation during leaching procedure (variable $\mathrm{X}_{7}$ ) and the sulphuric acid molar concentration (variable $\mathrm{X}_{8}$ ).

Today, the most widely used experimental design to estimate main effects as well as interaction effects is the $2^{\mathrm{n}}$ factorial design, where each variable is investigated at two levels (Montgomery, D.C., 1976; Sayen and Bayramogly, 2001). As the number of factors (n) increases, the number of runs for a complete replicate of the design also increases rapidly. Modeling can be performed using the first order model, defined by the equation:

$$
\mathrm{y}=\mathrm{b}_{\mathrm{o}}+\sum_{i=1}^{n} b_{i} x_{i}+\sum_{i=1}^{n} \sum_{j>1}^{n} b_{i j} x_{i} x_{j}
$$

Or the second order model, which is:

$$
\mathrm{y}=\mathrm{b}_{\mathrm{o}}+\sum_{i=1}^{n} b_{i} x_{i}+\sum_{i=1}^{n} b_{i i}\left(x_{i}{ }^{2}-\overline{x_{i}{ }^{2}}\right)+\sum_{i=1}^{n} \sum_{j>1}^{n} b_{i j} x_{i} x_{j}
$$

Where:

$$
\overline{X_{i}^{2}}=\frac{1}{N} \sum_{i=1}^{N} x_{i}^{2}
$$

Where $\mathrm{N}$ is the total number of experiments, including the central replicates.

This way, with following approximation:

$$
\mathrm{b}_{\mathrm{o}}{ }^{\prime}=\mathrm{b}_{\mathrm{o}}-\sum_{i=1}^{n} b_{i j} \overline{x_{i}^{2}}
$$

The second order model can be presented as:

$$
\mathrm{y}=\mathrm{b}_{\mathrm{o}}{ }+\sum_{i=1}^{n} b_{i} x_{i}+\sum_{i=1}^{n} b_{i i} x_{i}{ }^{2}+\sum_{i=1}^{n} \sum_{j>1}^{n} b_{i j} x_{i} x_{j}
$$

The decision considering the application of the first, or the second order model depends on the overall curvature generated by pure second order effects, which can be calculated as:

$$
\mathrm{LOF}_{\text {curv }}=\frac{m_{O} \cdot F \cdot\left(\overline{y_{1}}-\overline{y_{0}}\right)^{2}}{m_{o} \cdot F}
$$

Where $\sharp_{1}$ is the mean of factorial experiments results, and ${y_{0}}_{0}$ is the mean of central replicates, $F$ is the number of experiments in factorial design without central replicates.

If the variance analysis indicates that the overall curvature effect is significant, auxiliary experiments are carried out to develop a second order model.

\section{RESULTS AND DISCUSSION}

As already indicated, eight factors were chosen as independent variables, and their high and low levels were decided as shown in Table 1.

In the planning and analysis of experimental designs, normalized values are usually used instead of absolute values of the variables. The normalized value of an input variable is calculated as $\left(\mathrm{X}_{\mathrm{i}}-\mathrm{min}\right) /$ ( $\max -\min )$. This way, instead of absolute values presented in Table 1, normalized values fall between 0 and 1 .

With eight factors there are $2^{8}=256$ potential experimental setups. However, after introduction of all input variables into SPSS software (SPSS v. 18) it resulted with the factorial design that requires 27 runs. Six 
central replicates were added to the experimental plan to estimate pure experimental errors. The experiments were run in random order to avoid systematic errors.

Table 1. Factor levels

\begin{tabular}{|l|l|l|l|}
\hline Factors & $\begin{array}{l}\text { High level } \\
(+)\end{array}$ & $\begin{array}{l}\text { Medium level } \\
(0)\end{array}$ & $\begin{array}{l}\text { Low level } \\
(-)\end{array}$ \\
\hline$X_{1}$ & 100 & 50 & 10 \\
\hline$X_{2}$ & 250 & 150 & 25 \\
\hline$X_{3}$ & 12 & 6 & 1 \\
\hline$X_{4}$ & 1 & 0.5 & 0.25 \\
\hline$X_{5}$ & 80 & 50 & 25 \\
\hline$X_{6}$ & 60 & 40 & 20 \\
\hline$X_{7}$ & 600 & 300 & 100 \\
\hline$X_{8}$ & 1.5 & 1 & 0.4 \\
\hline
\end{tabular}

After conducting all 33 experiments, results of copper extraction were included in the database as the output variable. After calculating overall curvature, using the equation 6 , a first order model was chosen to fit the experimental data (Equation 1). The database, presented in table 1, was used for modeling procedure based on the first order model. For such model, ANOVA test vas performed. The values of obtained model coefficients which have statistical significance $(p<0.01)$ are presented in Table 2.

Dependence between experimentally determined copper extraction and the values obtained using the model is presented in Figure 1. Considering the low coefficient of determination $\left(\mathrm{R}^{2}=0.393\right)$, further adjustment of the modeling equation was performed after applying the Multiple Linear Regression Analysis (MLRA) of the starting model equation. Finally obtained model equation can be written as:

$$
\begin{aligned}
& \mathrm{Y}=-30.513+0.401 * \mathrm{X}_{1}-0.743 * \mathrm{X}_{5}+0.819 * \mathrm{X}_{6}- \\
& -0.001 * \mathrm{X}_{1} \mathrm{X}_{2}-0.002 * \mathrm{X}_{1} \mathrm{X}_{5}-0.219 * \mathrm{X}_{2} \mathrm{X}_{4}+ \\
& +0.004 * \mathrm{X}_{2} \mathrm{X}_{5}+0.075 * \mathrm{X}_{2} \mathrm{X}_{8}+5.215 * \mathrm{X}_{3} \mathrm{X}_{4}- \\
& -0.108 * \mathrm{X}_{3} \mathrm{X}_{6}+0.002 * \mathrm{X}_{3} \mathrm{X}_{7}-0.793 * \mathrm{X}_{3} \mathrm{X}_{8}+ \\
& +0.314 * \mathrm{X}_{5} \mathrm{X}_{8}
\end{aligned}
$$

Coefficient of determination of the final model is $\mathrm{R}^{2}=0.634$, as indicated in Figure 2 .

Table 2. Model of the process of copper extraction from flotation waste

\begin{tabular}{|l|l|l|l|l|l|}
\hline Model & B unstand & St. error & $\begin{array}{l}\text { Beta } \\
\text { standardized }\end{array}$ & $t$ & Sig. \\
\hline constant & -60.268 & 18.319 & & -3.29 & 0.004 \\
\hline $\mathrm{X}_{1}$ & 1.649 & 0.4 & 3.2 & 4.119 & 0.001 \\
\hline $\mathrm{X}_{5}$ & -1.877 & 0.456 & -2.226 & -4.114 & 0.001 \\
\hline $\mathrm{X}_{6}$ & 1.561 & 0.304 & 1.409 & 5.14 & 0.000 \\
\hline $\mathrm{X}_{1} \mathrm{X}_{2}$ & -0.003 & 0.001 & -1.509 & -3.097 & 0.007 \\
\hline $\mathrm{X}_{1} \mathrm{X}_{5}$ & -0.009 & 0.004 & -1.125 & -2.394 & 0.028 \\
\hline $\mathrm{X}_{2} \mathrm{X}_{4}$ & -0.442 & 0.089 & -1.772 & -4.954 & 0.000 \\
\hline $\mathrm{X}_{2} \mathrm{X}_{5}$ & 0.008 & 0.002 & 2.718 & 5.457 & 0.000 \\
\hline $\mathrm{X}_{2} \mathrm{X}_{8}$ & 0.102 & 0.052 & 0.642 & 1.972 & 0.065 \\
\hline $\mathrm{X}_{3} \mathrm{X}_{4}$ & 11.068 & 2.209 & 2.075 & 5.01 & 0.000 \\
\hline $\mathrm{X}_{3} \mathrm{X}_{6}$ & -0.236 & 0.062 & -3.123 & -4.264 & 0.001 \\
\hline $\mathrm{X}_{3} \mathrm{X}_{7}$ & 0.009 & 0.003 & 1.888 & 3.000 & 0.008 \\
\hline $\mathrm{X}_{3} \mathrm{X}_{8}$ & -2.956 & 1.162 & -0.928 & -2.544 & 0.021 \\
\hline $\mathrm{X}_{5} \mathrm{X}_{7}$ & 0.001 & 0.000 & 1.105 & 3.255 & 0.005 \\
\hline $\mathrm{X}_{5} \mathrm{X}_{8}$ & 0.931 & 0.229 & 1.714 & 4.067 & 0.001 \\
\hline
\end{tabular}




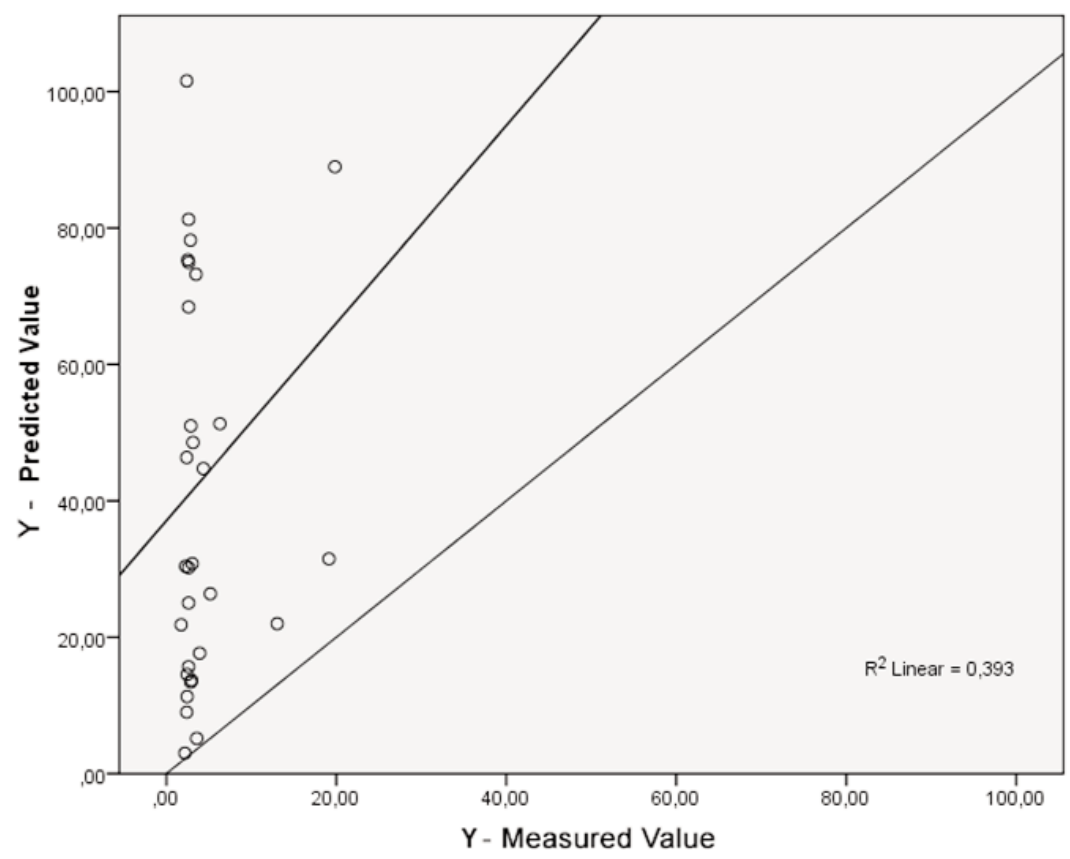

Figure 1. Dependence between the calculated and measured values of the copper extraction from the flotation waste $\left({ }_{-}=\right.$regression lines; $o=$ values calculated $u$ sing the starting model)

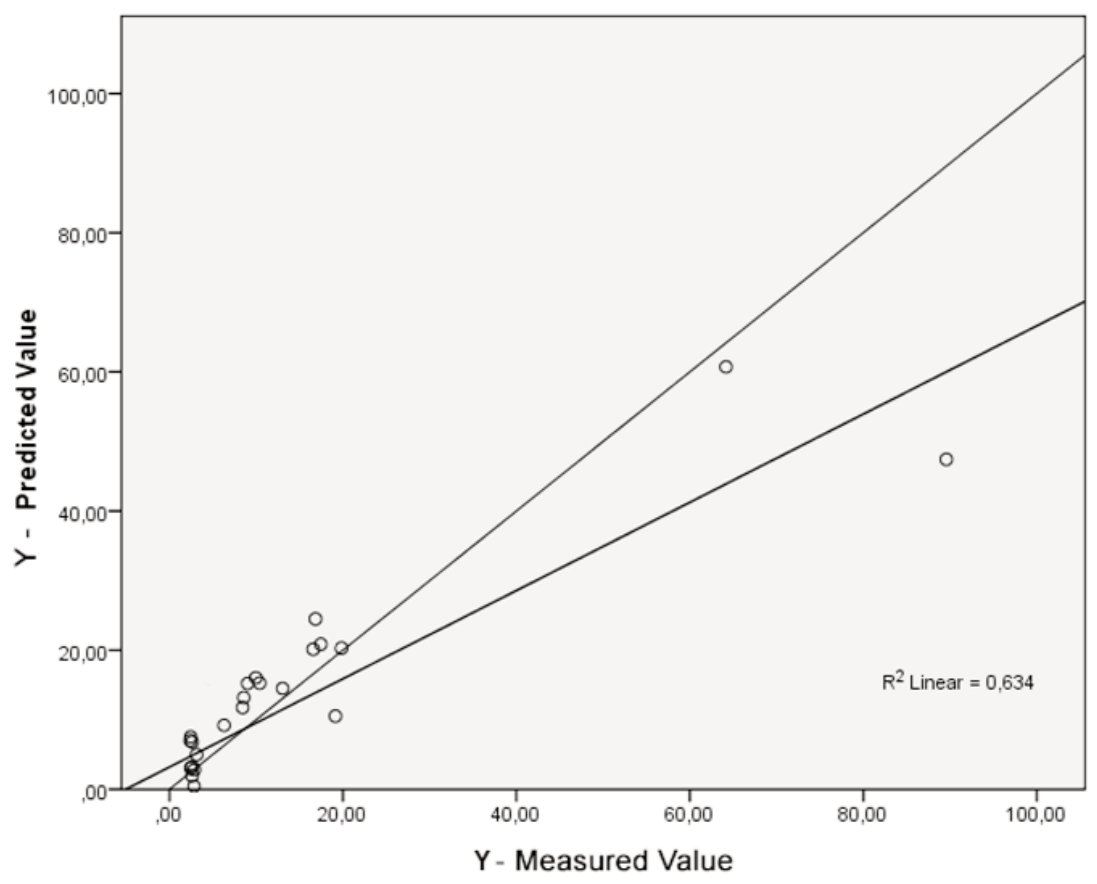

Figure 2. Correlation between experimentally determined and model predicted values of the copper extraction from the flotation waste $(-=$ regression lines; $o=$ values calculated using the final MLRA model) 
Using the final model equation (Equation 7), which predicts the real output of the investigated system accurately enough $\left(\mathrm{R}^{2}=\right.$ 0.634 ), it is possible to determine optimal conditionc for operations management of the copper extraction process. For optimization purposes Mat Lab software (mathworks.com) was used.

To determine the optimal experimental conditions, model equation (Eq. 7) is extrapolated on different combinations of the set of two characteristic variables, while keeping constant values of remaining six variables. Values of optimal copper extraction, depending on different combination of input variables are presented in Figure 3.
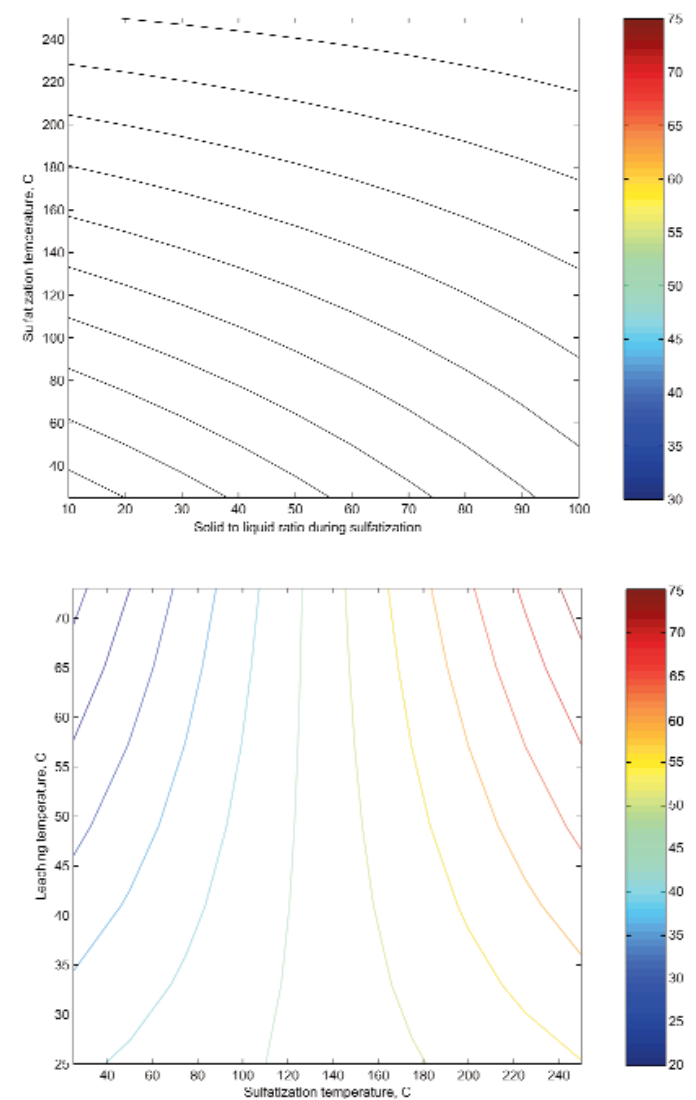

\section{CONCLUSIONS}

This paper presents an example of developing one real technological process model, aiming to optimize its operations management. The primary goal was to obtain applicable model which can be used to determine optimal technical conditions of the process. Besides technical, both economical and ecological parameters of the process were considered when determining the optimal conditions for copper extraction from the flotation waste. It was determined that presented model can be used to determine the optimal conditions of the investigated process. Profit, resulting after selling the copper produced from this raw material, could be used for remediation of this tailing pond.
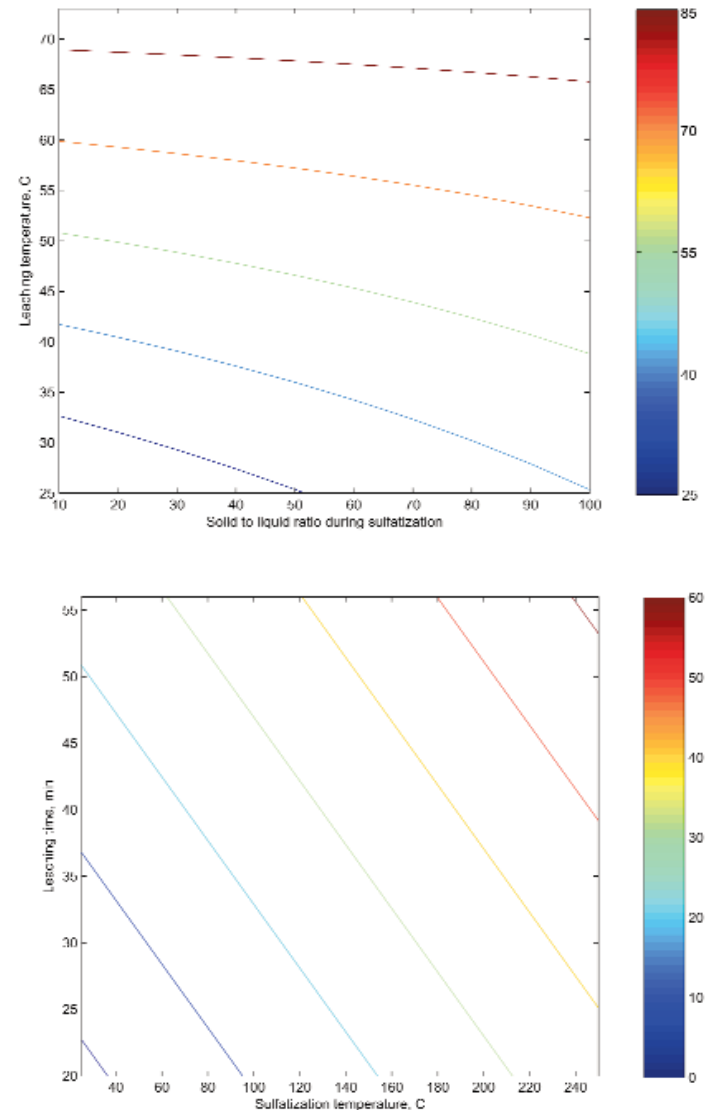

Figure 3. Determination of the optimal copper extraction based on the final mathematical model 


\title{
МОДЕЛОВАЊЕ ТЕХНОЛОШКОГ ПРОЦЕСА У ЦИЉУ УНАПРЕБЕЊА ЊЕГОВОГ ОПЕРАТИВНОГ УПРАВЉАЊА
}

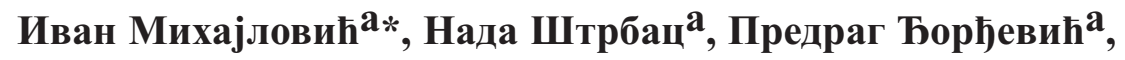 \\ Александра Ивановић

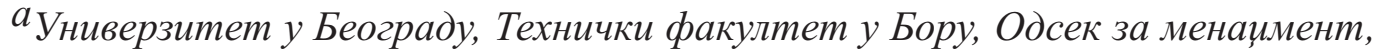 \\ Војске Југославије 12, 19210 Бор, Србија

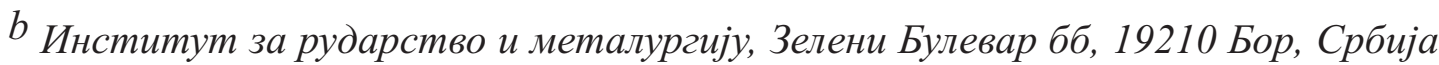

\section{Извод}

Овај рад представља процедуру моделовања једног реалног технолошког система. Објекат моделовања је систем издвајања бакра из флотацијске јаловине која се акумулира у оквиру Рударско топионичарског басена Бор (Србија). Адекватна база података за процес статистичког моделовања конструисана је употребом ортогоналног факторског дизајна експеримената. Математички модел испитиваног система урађен је комбинацијом линеарног и вишеструког линеарног статистичког приступа. Циљ оваквог модела је да се добију оптимална стања система, која би омогућила ефикасно оперативно управљање разматраним процесом. Поред технолошких и економских, еколошки параметри процеса су узети у обзир као важне карактеристике окружења система..

Кључне речи: Моделовање процеса, Статистичка анализа, дизајн експеримената

Announcement: Research presented in this paper is financially supported by Serbian Ministry of education and science, under the project TR 34023.

\section{References}

Brown, C. (2007). Differential Equations - A Modeling Approach, Sage Publications.

Giraldo-Zuniga, A.D., Arevalo-Pinedo, A., Rodrigues, R.M., Lima, C.S., Feitosa, A.C. (2006) Kinetic drying experimental data and mathematical model for jackfruit slices. Cienc. Technol. Aliment., 5(2): 89-92.

Đorđević, P., Mihajlović, I. and Živković, Ž. (2010) Comparison of linear and nonlinear statistics methods applied in industrial process modeling procedure.
Serbian Journal of Management 5 (2): 189 198.

European Union, "Council Directive 96/61/EC of 24 September 1996 concerning integrated pollution prevention and control", Official Journal L 257, 10/10/1996, pp. 0026 - 0040 .

European Union, "Council Directive 2006/21/EC of 15 March 2006 on the management of waste from extractive industries and amending Directive 
2004/35/ECl", Official Journal L 102, 11/4/2006, pp. 15 - 33.

Meijie, Z., Huazhi, G., Ao, H., Hongxi, Z., Chengji, D. (2011) Numerical simulation and industrial practice of inclusion removal from molten steel by bas bottom-blowing in continuous casting tundish. Journal of Mining and Metallurgy, Section B: Metallurgy, 47(2) B: 137-149.

Mihajlović, I., Nikolić, Đ. and Jovanović, A. (2009). Systems theory, Bor, Serbia, Technical faculty in Bor. (in Serbian)

Mihajlović, I., Nikolić, Đ., Štrbac, M., Živković, Ž. (2010). Statistical Modelling in Ecological Management Using the Artificial Neural Networks (ANNs), Serbian Journal of Mangement, 5(1): 39-50.

Montgomery, D.C. (1976). Design and Analysis of Experiments, New York, USA, John Wiley and Sons.

Sayen, E., Bayramogly, M. (2001). Statistical Modelling of Sulphuric Acid Leaching of $\mathrm{TiO}_{2}, \mathrm{Fe}_{2} \mathrm{O}_{3}$ and $\mathrm{Al}_{2} \mathrm{O}_{3}$ From Red Mud, Trans IchemE, 79 B: 291 - 296.

SPSS inc. PASW Statistics 18, Predictive Analysis Software Portfolio, www.spss.com

Taylor, C.F., Paton, N.W., Garwood, K.L.(2003). A systematic approach to modeling, capturing, and disseminating proteomics experimental data, Nature Biotechnology, 21: 247 - 254.

Weir, G. (1991). Differential Equations A Modeling Approach, Boston, Massachusetts, USA, Addison-Wesley.

http://www.mathworks.com/products/mat lab/index.html 